\title{
INFLUENCES ON HAPPINESS AND SUBJECTIVE WELL-BEING OF ENTREPRENEURS AND LABOUR: KWAZULU-NATAL Case STUdy
}

\author{
Darma Mahadea
}

School of Economics and Finance, University of KwaZulu-Natal

\section{Shaun Ramroop}

School of Mathematics, Statistics and Computer Science, University of KwaZulu-Natal

Accepted: November 2014

\begin{abstract}
Globally, individuals seek happiness, but not everybody is happy. Economic reasoning suggests that rising incomes with expansions in GDP enhance the quality of life and subjective well-being. This paper examines the influences on individual happiness, using ordinal logistic regression and chi-square analyses. Based on the findings of a small case study, the chi-square test indicated that a significant relationship exists between gender, education, ethnicity, children, marital status, employment relations, income and self-reported happiness. The study also found that, on average, happier people tended to be educated, married with children, and treated fairly at work. But having too many children produced a decrement in individual happiness. The ordinal regression results indicate that an individual's education, gender, age distribution and work environment are influential in producing higher levels of happiness. Entrepreneurs were found to have a significantly higher mean level of happiness than employees. In the workplace, individuals who experienced personal growth and were able to contribute their ideas tended to be happier, relative to others who perceived themselves to be 'restricted'.
\end{abstract}

Key words: happiness, subjective well-being, education, entrepreneur, labour, gender, income, work environment

JEL: A1, D1, D6, J1

\section{$1 \quad$ Introduction}

The search for individual happiness and a better life is a goal sought after in both rich, developed and poor, developing countries. All of us want to have better homes, cars, household items and other assets, and lead more abundant lives. Yet, not everybody is happy. Historically, happiness or subjective well-being has been a major research interest for philosophers. In recent years, social scientists, neuroscientists and psychologists have also been engaged in research on human happiness (Layard, 2011).

Philosophers have probed happiness by looking at the maximisation of pleasure and virtuous human qualities that contribute to a good, eudemonic life (Bruni \& Porta, 2007). Jeremy Bentham argued that every person strives to become happy by maximising pleasure and minimising pain. Our experience of well-being is greatly influenced by wealth and our relationships or connections with other people. Accordingly, some social scientists consider the influence of wealth, income, consumption, friendships, family relationships, emotions and communities as critical for happiness (Sen, 2010; Huffington, 2014).

As economic growth increases real per capita income, people can afford to buy superior goods and services. The more income individuals earn, the greater the number of needs that can be satisfied, resulting in greater levels of utility. The higher resulting income gains contribute to poverty alleviation and enhanced life satisfaction (Layard, 2006). More recently, top policymakers in countries as different as Brazil and Great Britain, seem to support the measurement of gross national happiness (GNH), or general well-being (GWB) rather than gross domestic product 
(GDP), as a measure of prosperity (Porter, 2011). Pursuing GNH rather than GDP seems to have yielded positive contentment results in Bhutan in recent decades (Sachs, 2012). However, in the case of South Africa, according to the World Database of Happiness, the average level of happiness or life satisfaction has decreased from 6.8 in 2006 to 6.31 in 2007 and to 4.95 in 2008 (Veenhoven, 2012). The New Foundation Economics indicates that while South Africa's 'Happy Planet' index was a low 28.2 in 2013: its citizens' experienced well-being was at 4.7, relatively lower than those of the U.K (7) or India (5). These figures reflect that individuals in South Africa are currently experiencing, on average, a reduced level of life satisfaction.

Various factors contribute to individual happiness and life satisfaction. Using ordinal logistic regression, this paper examines the influences on happiness with reference to different groups, on the basis of a survey relating to respondents' subjective well-being in central Pietermaritzburg, the capital of the KwaZulu-Natal province, South Africa. As a secondary objective, the paper examines whether there are correlations between individual happiness, gender, education, ethnicity, marital status, children, work function, income and employment status. This is done by using the exact chi-square test. The paper then uses an analysis of variance (ANOVA) and the Least Squared Differences (LSD) approach to examine where the differences are located in the average happiness levels among demographic variables, education, income and employment status, as entrepreneurs and labour. The paper consists of four sections. First, there is a literature review on happiness. The second section highlights the research methodology. This is followed by statistical analyses, involving descriptive statistics, chi-square tests and a logistic regression. The last section covers a discussion of the results and concludes with some happiness-enhancing suggestions.

\section{Literature review}

Veenhoven (1993) defines happiness as the degree to which an individual judges the overall quality of his or her life as being favourable. Viewed narrowly, happiness is associated with hedonism, a mental state of feeling good or enjoying brief feelings of pleasure, and avoidance of pain (Kahneman, 2012). To Aristotle, happiness is a form of the good life associated with virtuous activities and moral actions. Jeremy Bentham, the founder of Utilitarian philosophy, argues that the individual's conduct as well as government policies should be directed toward minimising pain and promoting the greatest happiness for the greatest number of people.

Economics has traditionally viewed happiness in terms of subjective well-being (Frey \& Stutzer, 2000). Oswald (1997) views happiness as 'pleasure' or 'satisfaction', while Layard (2011) regards happiness as enjoying life and feeling good, synonymous with life satisfaction or subjective well-being (SWB). Individuals are said to have high SWB if they experience a high degree of life satisfaction and frequent pleasant emotions such as joy and affection, and only infrequently experience unpleasant emotions. Easterlin (2001:465) views happiness in a broader way: "I use the terms happiness, subjective well-being, satisfaction, utility, welfare interchangeably." The terms of these social scientists relating to happiness are used in this study.

Daniel Kahneman (2012), the Nobel Prize winner for Economics in 2002, treats happiness as a subjective issue that is measurable through surveys. A typical question in a survey on this theme might be: "Taking all things together, would you say you are very happy, quite happy, or not very happy?" (Layard, 2011). Respondents would rate their level of happiness on a scale (1 to 10), at a given moment and over time (Seligman, 2004). In evaluating human happiness, it is sensible in Economics to rely on the judgments of people as they are regarded to be the best judges of the overall quality of their own lives (Frey \& Stutzer, 2002). According to Stutzer (2001:37), the measures of subjective well-being have a "high consistency, reliability and validity", as well as high stability over time.

\subsection{Income and happiness}

In order to enhance citizens' well-being in a society, one needs to understand what influences their happiness levels. Economic literature suggests a link between happiness and income, particularly 
in societies with low real per capita GDP (Layard, 2011). People with higher incomes tend to have a higher status in society, intrinsically making them happier and enabling them to buy positional goods. These are expensive goods that are scarce, and the ability to afford them is limited to wealthy individuals, so in this absolute or socially imposed sense "income does buy happiness" (Frey \& Stutzer, 2002:40).

Each individual wants money, not for its own sake per se, but for what it can bring to us in terms of happiness $(\mathrm{Ng}, 1997)$. More money makes people happier because they can buy more (Coyle, 2012). Even in the case of South African day labourers in the informal economy, Blaauw, Botha, Schenck and Schoeman (2013) found that income and its increase are important in bringing about happiness, particularly when individuals are poor and live in deprived communities. In developing countries, higher income raises the happiness of poor people living below the bread line, enabling them to meet basic needs.

In South Africa, a close relationship is found to exist between improved financial security and subjective well-being for black South Africans. Improved income contributes to material possessions and a higher social standing and subjective well-being of individuals (Moller, 2007; Mahadea \& Rawat, 2008; Botha \& Booysen, 2013). But as one's happiness increases and one moves away from being poor to rich, the level of contentedness starts to drop (Layard, 2011). Further, studies show that, on average, individuals in wealthier countries are happier than those in poorer countries, and this relationship between happiness and income holds at a particular point in time (Easterlin, 1995; Kenny, 2005).

Previous long-term studies on happiness in developed countries indicate that people there, on average, are currently no happier than in earlier times, although their real incomes have increased significantly (Easterlin, 1995; Frey \& Stutzer, 2002). This income-happiness nexus might seem like a paradox. However, recent studies involving fifty-two countries, covering time-series data for the period 1981-2007, show that happiness increases with income and entire nations are happier with an expansion in economic growth (Kenny, 2005; Veenhoven \& Hagerty, 2006; Inglehart, Foa, Peterson \& Weizel, 2008; Helliwell, Barrington-Leigh, Harris \& Huang, 2010). Similarly, on the basis of their research, Stevenson and Wolfers (2008:3) conclude: "There appears to be a very strong relationship between subjective well-being and income, which holds for both rich and poor countries". This prompts Diane Coyle (2012:51) to argue that "there is no paradox", leading to a "clear conclusion: economic growth contributes to happiness".

Easterlin (2001) argues that absolute income matters to individual happiness up to a point, but once basic needs are met, relative income matters more for happiness. People compare their incomes and styles of living with those of others in their reference group when evaluating their current level of subjective well-being. Studies in South Africa have also found that both absolute and relative income are important determinants of subjective well-being (Hinks \& Gruen, 2007; Mahadea \& Rawat, 2008; Botha \& Booysen, 2013; Blaauw \& Pretorius, 2013).

If people's aspirations do not change, a rise in income may increase subjective happiness. But as people earn higher levels of income, their aspirations usually change and they become habituated to a change in the standard of living. Some emulate the habits of celebrities or others, prompting them to buy more. They feel dissatisfied with what they have and may indulge in conspicuous consumption, possibly by contracting debt. This condition of 'affluenza', partly driven by consumerism, does not necessarily make them permanently happier (James, 2007; Frank, 1999; Dutt \& Radcliff, 2009).

Inequalities have negative effects on reported happiness in South Africa and other countries too (Posel \& Casale, 2011; Sachs, 2012). Societies with low income inequalities tend to be happier, with high levels of trust (Wilkinson \& Pickett, 2010). South Africa's perceived well-being or overall life satisfaction index over the period 2006-2010, is a low 4.7, which is below the average (4.9) of countries in a similar development group, and below the global average figure, 5.3 (HDR, 2011). The 2013 World Happiness Report also confirms that the average life satisfaction and happiness level (below 5) in South Africa is below the world average (Helliwell, Layard \& Sachs, 2013). 


\subsection{Work and happiness}

If individuals are free to choose career options, they may choose self-employment and entrepreneurship rather than wage-employment, if their happiness is higher in the former than in the latter (Headey, Muffels \& Wagner, 2010). The quality of relationships one has at work has a bearing on individual happiness. If we do not work or do not have a regular source of income, we may enjoy considerable leisure, but limited satisfaction, without money. Some individuals choose to work for a fixed income as employees, whereas others tend to create employment for themselves as entrepreneurs. These risk-takers earn a flexible income, depending on the financial success of their endeavours. Thus, entrepreneurs in self-employment and others in wage-earning employment who enjoy their work, are likely to be happier than those who are unemployed (Clark \& Oswald, 1994; Hundley, 2001).

In a working environment that offers scope for the individual to grow and participate in decision-making, employees feel respected or valued for their ideas and contributions to the firm. Satisfaction at work impacts positively on the intrinsic motivation of workers, productivity and business performance (Frey, 2008; Diener \& Biswas-Diener, 2008). Where there is workplace trust between labour and the entrepreneur or employer, and good opportunities for advancement, workers tend to be happy and are less likely to quit their existing jobs. In contrast, in a work environment where there is a lack of trust among members, workplace stress impacts adversely on the well-being of workers and entrepreneurs and on a company's bottom line (Huffington, 2014).

\subsection{Education, social capital and ethnic influences on happiness}

People who have skills and education are generally more productive, earn more and tend to be happier than those with less education or fewer skills (Sen, 2010). Hinks and Gruen (2007) found that individuals in South Africa with tertiary education are happier than those with no education. In the South African context of multiple ethnicities and the legacy of apartheid, the African population seems to have had lower levels of reported well-being relative to the white or other groups, all other factors being equal (Kingdon \& Knight, 2006; Moller, 2007; Posel \& Casale, 2011; Ebrahim, Botha \& Snowball, 2013; Blaauw \& Pretorius, 2013).

Further, individuals with social connectivity are less isolated, better supported, more bonded and happier than those with fewer social connections (Putman, 2000; Lane 2001). Social capital impacts positively on the well-being of individuals (Dutt \& Radcliff, 2009). Similarly, in the case of South Africa, and Gauteng's urban population, Powdthavee (2011) and Greyling (2011) found that individuals with better social ties, with children and friendships, and living in a good or safe community environment without high levels of crime or service delivery failures, are happier than those who live in communities where these qualities are lacking. At the family level in South Africa, Botha and Booysen (2013) found that having good family functioning and relationships are beneficial to individual and household happiness, and individuals from such family backgrounds have greater life satisfactions relative to those in dysfunctional families. Similarly, loving relationships and marriage are key conditions for happiness (Layard, 2011). Powdthavee (2007, 2011) found that South Africans in civil marriages are significantly happier than people who are single and have never married.

\section{Research objectives and methodology}

The primary objective is to determine the factors that influence the level of happiness among respondents in relation to certain reference groups. This is achieved through using an ordinal logistic regression. The secondary objective is to examine whether there are relationships among happiness, gender, education, ethnicity, marital status, children, work function, income and employment status, or whether these are independent factors. This is done by using the exact chisquare test for independence of factors. Using the analysis of variance (ANOVA) and the Least Squared Differences (LSD) approach, the paper also examines whether there are differences in the respondents' average happiness levels in relation to the above variables. 
Researchers need to gather information on different life domains to understand what makes for happiness (Veenhoven, 1997). Relevant data on the levels of self-reported happiness of the surveyed respondents were obtained by administering a pre-tested questionnaire in central Pietermaritzburg. The question on self-reported happiness has evident face validity, since it was adapted from existing questionnaires (Seligman, 2004; Bruni \& Porta, 2007). It is the subjects who make the appraisal of their subjective well-being or happiness, and who are deemed to be the best judges of their true level of life satisfaction.

\subsection{Sample particulars}

The sample consisted of 300 subjects (43 per cent male and 57 per cent female), selected by convenience sampling; 23.3 per cent were entrepreneurs, randomly chosen from a list of the small firm entrepreneurs, obtained from the Pietermaritzburg Chamber of Commerce; and the remainder were employees randomly chosen from various firms. To avoid any bias, the employees of the surveyed entrepreneurs' firms were not selected. Of the sample, 31 per cent were single, 56 per cent married, and 13 per cent were divorced or widowed. The ethnicity of the respondents was as follows: 23 per cent black, including one entrepreneur; 5.7 per cent coloured, including 2 entrepreneurs; 16.3 per cent Indian, including 7 entrepreneurs; and the remainder 55 per cent were white, including 60 entrepreneurs. With regard to age, 21.3 per cent were in the 18 -30 group; 38.3 per cent were in the 31 - 45 group; 30.3 per cent in the 46-59 category group; and 10 per cent were between 60 and 75 .

Consistent with other studies (Powdthavee, 2011; Seligman, 2004), happiness was measured on a Likert scale, from 1 to 5, with lower values indicating 'least happy' (1) and higher values reflecting 'extremely happy' (5). Income was measured along a continuum from low (R1000) to high (R18000 and above).

The questionnaire that was administered through face-to-face interviews, also sought information on the respondents' income, education, car and house ownership, pension and medical aid, relationships and demographic background. Questions relating to work environment and community involvement were measured on a five- point Likert scale. All these variables were treated as categorical factors. The data were analysed by using Stata and SPSS (version 21).

Reliability is the measure of internal consistency of a questionnaire. It can be reflected by the Cronbach's alpha, that ranges from 0 to 1 . Coakes and Steed (2003:140) state that there are a number of different reliability coefficients. One of the most commonly used is the Cronbach's alpha, which is based on the average correlation of items within a test if the items are standardised. If the items are not standardised, alpha is based on the average covariance among the items. In this case, the Cronbach's alpha was calculated for a set of four questions, relating to work environment: having friends at work; treatment at work; and experiencing personal growth at work; that have the same scales. The alpha value was 0.817 . As the rest of the questions comprising the questionnaire had different scales, the Cronbach's alpha cannot be calculated. When the results of the Cronbach's alpha are higher than 0.7, the alpha value is deemed acceptable.

\section{Statistical results}

\subsection{Descriptive statistics}

The majority of the people surveyed reported being happy. Only 8.6 per cent reported being 'not happy at all' or 'not very happy'; 34.3 per cent reported being 'fairly happy'; 40.3 per cent reported being 'very happy'; and the remainder (almost 17 per cent) reported being 'extremely happy'. Their gross monthly income ranged from R1000 to R18000 and over. 10.7 per cent of the respondents fell into the low income group, R1000-2000; 8 per cent in the R2001-R4000 group; 29.3 per cent earned between R4000 and R10000; 23.3 per cent earned between R10001-R18000; and about 29 per cent earned over R18000. 
The level of education of the respondents ranged from Grade 4 to the postgraduate level. Of the respondents, 10 per cent had an education level between Grade 4 and Grade 11; 41 per cent had a matric pass; 26 per cent had a diploma; 12 per cent had a university degree or tertiary education; and 11 per cent had a postgraduate education.

Of the respondents, women reported an average happiness level of 3.54, that was marginally lower than that of the men (3.68). Almost 56 per cent of the surveyed subjects were married and 11 per cent were divorced, with the remainder being single or widowed. Married people were reportedly happiest, with a mean happiness score of 3.72. Single people had a mean happiness score of 3.50, divorced people had a mean happiness level of 3.38 and widowed people had an average happiness score of 3.3 .

\subsection{Differences in average happiness}

As far as the average happiness scores for different factors were concerned, males (3.685) were slightly happier than females (3.547) and respondents with a tertiary degree education (3.833) were happier than those with a primary and secondary education (Table 1). Indians and whites (3.7) were happier than subjects in the black (3.1) and coloured (3.4) race groups. The effect on happiness of having children and of the number of children was mixed. Those respondents with one child and two to three children (3.7) were happier than those respondents who had four or more children (3.1). The differences were significant. Frey and Stutzer $(1999,2000)$ found that having many children has a negative effect on household happiness, possibly because children increase stress levels of parents, particularly for low income earners who have to distribute limited resources thinly among many members. The self-employed (3.9) were on average also significantly happier than the wage-employed respondents (3.5), and respondents who were employed in a clerical capacity were the least happy. Similarly, using survey data from Great Britain and USA, Blanchflower and Oswald (1992) found that self-employed individuals in entrepreneurial endeavours are happier than those who work as employees. Finally, those respondents earning above R4000 monthly were happier (with an average score above 3.6) than those respondents earning below R4000 (average score below 3.5). The independent sample t-test did not show any statistical difference between males and females in their mean happiness levels.

The ANOVA was also used to check for differences amongst the demographic variables with respect to the average happiness levels. Once the differences in the means were found, multiple comparisons in the form of Least Squared Differences (LSD) were used to ascertain exactly where the differences were located between the levels of the factors. The ANOVA assumptions were also checked and none were found to be sufficiently violated to warrant the use of a robust ANOVA. As is evident in Table 1 below, significant differences existed in the education group $(\mathrm{F}=4.78, \mathrm{p}$ value $=0.01)$; ethnic group $(\mathrm{F}=10.127$, $\mathrm{p}$-value $=0.000)$; number of children $(\mathrm{F}=3.18$, $\mathrm{p}$-value $=0.024)$; and the current gross income group $(\mathrm{F}=13.783$, $\mathrm{p}$-value=.000). The ANOVA also showed a significant difference in the marital status group $(\mathrm{F}=9.93$, $\mathrm{p}$-value $=.000)$, alluding to the fact that there were differences in the mean happiness level within the four categories. Of significance, married people were found to be happier on average than those who were single, divorced and widowed. With regard to the current gross monthly income earned, there were also significant differences within this group with the over- R18000 level having the highest mean level of happiness (3.8), as compared to the rest of the levels within that group. This clearly indicates that income does have a significant influence on the level of happiness.

The LSD multiple comparisons were also used to check for differences between each level of education, ethnic group, marital status and current gross income, and it was found that all the levels differed one from another. The statistically significant differences within the levels of the demographic variables (ethnic group, education and current gross income) are consistent with the empirical findings of Botha and Booysen (2013), Blaauw and Pretorius (2013), and Moller (2011). Furthermore, the independent sample t-test was used to check for differences between the wage earners and the self-employed entrepreneurs ( $\mathrm{t}$-statistic $=-3.807, \mathrm{p}$-value $=0.000)$ and there was a statistical difference in this group. Entrepreneurs were thus found to be happier than wage-earners, 
a result that supports the findings of Benz and Frey (2008), and Blanchflower and Oswald (1992). The ANOVA revealed a significant difference in the work function group $(\mathrm{F}=7.971$, $\mathrm{p}$-value $=.000$ ). Respondents in the owner employment group had a higher average level of happiness (3.9) than the rest of the categories of the employment group i.e. clerical, operator, administration/management and other. This is also linked to the fact that in the current case study setting, entrepreneurs and self-employed respondents were happier than wage earners. The LSD also showed significant differences in the average level of happiness within the different categories of that group.

Table 1

Summary of respondents' characteristics and average happiness

\begin{tabular}{|c|c|c|c|c|}
\hline & Variable & Frequency & Percentage & $\begin{array}{c}\text { Average } \\
\text { happiness }\end{array}$ \\
\hline \multirow{4}{*}{ Age } & $18-30$ & 64 & 21.3 & 3.671 \\
\hline & $31-45$ & 115 & 38.3 & 3.548 \\
\hline & $46-59$ & 91 & 30.3 & 3.626 \\
\hline & $60-75$ & 30 & 10.0 & 3.633 \\
\hline \multirow{2}{*}{ Gender } & Male & 130 & 43.3 & 3.685 \\
\hline & Female & 170 & 56.7 & 3.547 \\
\hline \multirow{5}{*}{ Education } & Grade 4-11 & 30 & 10.0 & $3.033^{*}$ \\
\hline & Matric & 123 & 41.0 & $3.577^{*}$ \\
\hline & Diploma & 78 & 26.0 & $3.731^{*}$ \\
\hline & Degree & 36 & 12.0 & $3.833^{*}$ \\
\hline & Postgraduate & 33 & 11.0 & $3.697^{*}$ \\
\hline \multirow{4}{*}{ Ethnic group } & Black & 68 & 22.7 & $3.132^{*}$ \\
\hline & Coloured & 17 & 5.7 & $3.471^{*}$ \\
\hline & Indian & 49 & 16.3 & $3.735^{\star}$ \\
\hline & White & 166 & 55.3 & $3.777^{*}$ \\
\hline \multirow{4}{*}{$\begin{array}{l}\text { Marital } \\
\text { status }\end{array}$} & Single & 94 & 31.3 & $3.500^{*}$ \\
\hline & Married & 167 & 55.7 & $3.723^{*}$ \\
\hline & Divorced & 32 & 10.7 & $3.375^{*}$ \\
\hline & Widowed & 7 & 2.3 & $3.286^{*}$ \\
\hline \multirow{4}{*}{$\begin{array}{l}\text { No. of } \\
\text { children }\end{array}$} & No children & 79 & 26.3 & 3.494 \\
\hline & 1 Child & 56 & 18.7 & $3.661^{*}$ \\
\hline & 2-3 Children & 147 & 49.0 & $3.701^{*}$ \\
\hline & 4 or more & 18 & 6.0 & $3.167^{*}$ \\
\hline \multirow{2}{*}{$\begin{array}{l}\text { Employment } \\
\text { status }\end{array}$} & Wage employed & 230 & 76.7 & $3.504^{*}$ \\
\hline & Self employed & 70 & 23.3 & $3.943^{*}$ \\
\hline \multirow{5}{*}{$\begin{array}{l}\text { Work } \\
\text { function }\end{array}$} & Clerical & 46 & 15.3 & $2.978^{*}$ \\
\hline & Operator & 59 & 19.7 & $3.678^{*}$ \\
\hline & Admin/management & 80 & 26.7 & $3.613^{*}$ \\
\hline & Owner & 70 & 23.3 & $3.969^{*}$ \\
\hline & Other & 45 & 15.0 & $3.628^{*}$ \\
\hline \multirow{5}{*}{$\begin{array}{l}\text { Current } \\
\text { gross } \\
\text { income }\end{array}$} & R1000-2000 & 32 & 10.7 & $2.781^{*}$ \\
\hline & R2000-4000 & 24 & 8.0 & $3.458^{*}$ \\
\hline & R4000-10000 & 88 & 29.3 & $3.671^{*}$ \\
\hline & R10000-18000 & 70 & 23.3 & $3.614^{*}$ \\
\hline & Over R18000 & 86 & 28.7 & $3.884^{*}$ \\
\hline
\end{tabular}

* Significant differences at the 5 per cent level 


\subsection{Chi-square test of independence of factors}

Coakes and Steed (2003:195) state that there are two main types of chi-square test. The chi-square test for the goodness of fit applies to the analysis of a single categorical variable, and the chisquare test for independence or relatedness applies to the analysis of the relationship between two categorical variables. Each of the demographic variables was cross- tabulated with the level of happiness to check for significant relationships. Some of the cells had less than five responses per cell and this violated one of the assumptions of the chi-square test. In order to overcome this problem, the exact chi-square test was used. The latter test makes use of an iterative technique, unlike the conventional chi-square test, in order to process the expected values, and then uses these values to calculate the test statistic which is the sum of the squared differences between the observed and expected values, divided by the expected values. This technique is used extensively in social science research in order to compensate for the violation of the minimum of five responses per cell assumption (Devore \& Berk, 2012).

The results of the exact chi-square test are presented below (Table 2). These indicate significant happiness relationships at the 5 per cent level. Happiness seems to be independent of age, but other research indicates a U-shaped relationship between age and happiness (Easterlin, 1995; The Economist, 2010). However, there are significant relationships between the levels of happiness and gender ( $\mathrm{p}=0.047)$; between happiness and education $(\mathrm{p}=0.000)$; happiness and marital status $(\mathrm{p}=$ $0.047)$; happiness and the number of children in the family $(\mathrm{p}=0.000)$; happiness and the employment status $(\mathrm{p}=0.015)$; and happiness and the work function of individuals $(\mathrm{p}=0.000)$; happiness and ethnic group ( $\mathrm{p}=0.000)$, and finally the level of happiness was strongly associated with the respondent's current gross income $(\mathrm{p}=0.000)$. These findings tend to confirm the earlier results, shown in Table 1. On average, male respondents tended to be happier than female. This finding seems to be in line with those of Posel and Casale (2011) and Layard (2011). Blaauw and Pretorius (2013), using the National Income Dynamics Survey dataset in South Africa, also found that females overall had lower levels of well-being relative to males, but surprisingly, the interacting variable between married males and married females indicated that married females were happier than their male counterparts. Married people with children and education were found to be happier than others who were single and uneducated. Subjective well-being seemed to vary with ethnicity and nature of employment: whites and self-employed individuals were found to have, on average, a higher level of happiness relative to those in other groups. As indicated by the chi-square statistic (93.247), a strong relationship existed between gross income and happiness (Table 2).

Table 2

Summary of chi-square statistics

\begin{tabular}{|l|c|c|}
\hline \multicolumn{1}{|c|}{ Variables } & $\begin{array}{c}\text { Chi-square } \\
\text { test statistic }\end{array}$ & P-value \\
\hline Happiness and Age & 12.057 & 0.441 \\
\hline Happiness and Gender & 21.266 & $0.047^{*}$ \\
\hline Happiness and Education & 29.218 & $0.000^{*}$ \\
\hline Happiness and Ethnic group & 45.881 & $0.000^{*}$ \\
\hline Happiness and Marital Status & 21.213 & $0.047^{*}$ \\
\hline Happiness and Children & 54.354 & $0.000^{*}$ \\
\hline Happiness and Employment status & 12.273 & $0.015^{*}$ \\
\hline Happiness and Work function & 29.535 & $0.000^{*}$ \\
\hline Happiness and Current gross income & 93.247 & $0.000^{*}$ \\
\hline
\end{tabular}

*Significant at the 5 per cent level

In order to examine the levels of happiness against the demographic variables as well as some of the other surveyed variables of work function, it is logical to use the ordinal logistic regression. This statistical method is used when a dependent variable, as in the present case of the level of happiness, has more than two categories and this is regressed against a set of explanatory variables 
comprising demographic (ethnicity, gender, education, employment status and age) and work function (personal growth and ideas contribution) variables. The results of the ordinal logistic regression are presented in the following section.

\subsection{Ordinal logistic regression}

Ordinal logistic regression is a modelling tool widely applied to data particularly where an ordinal nature is present or has been created. Some of the ordinal logistic regression models include the proportional odds model (POM); the partial proportional odds model-without restrictions (PPOMUR) and with restrictions (PPOM-R); the continuous ratio model (CRM); and the stereotype model (SM) (Williams, 2006). The most frequently used ordinal logistic regression model in practice is the constrained cumulative logit model called the proportional odds model (Agresti, 2006; Allison, 2005). All of the abovementioned models have their unique strengths and weaknesses.

The current study started by applying the proportional odds model which has the assumption of proportional odds/parallel lines attached to it. However when this assumption is violated, one has to move on to the partial proportional odds model which relaxes the proportional odds/parallel lines assumption in relation to any of the explanatory variables that have violated this assumption. We have used Stata version 13 to carry out our analyses. Williams (2006) states that the general form of the POM model is given as:

$$
P\left(Y_{i}>j\right)=g(X \beta)=\frac{\exp \left(\alpha_{j}+X_{i} \beta\right)}{1+\left\{\exp \left(\alpha_{j}+X_{i} \beta\right)\right\}}, j=1,2, \ldots, M-1
$$

where $\mathrm{M}$ is the number of categories of the ordinal dependent variable, $\alpha_{j}$ is the constant and $X_{i}$ are the explanatory variables with coefficients $\beta$. When the parallel lines assumption is met then the $\beta$ 's (not the $\alpha^{\prime} s$ ) are the same for all values of $j$. A common problem in the POM model is that the parallel lines assumption is often violated and one or more of the the $\beta$ 's differ across values of $j$, and hence we have partial proportional odds. Williams (2006) gives an example of this where he states that in the PPOM, some of the $\beta$ coefficients can be the same for all values of $j$ while others can differ. For example, in the following expression, the $\beta$ 's for X1 and X2 are the same for all values of $j$ but the $\beta$ 's for X3 are free to differ, i.e.

$$
P\left(Y_{i}>j\right)=\frac{\exp \left(\alpha_{j} x 1_{i} \beta 1+x 2_{i} \beta 2+x 3_{i} \beta 3_{j}\right)}{1+\left\{\exp \left(\alpha_{j}+x 1_{i} \beta 1+x 2_{i} \beta 2+x 3_{i} \beta 3_{j}\right)\right\}}, j=1,2, \ldots, M-1
$$

This exemplifies the aspect of the parallel lines assumption. In order to test the parallel lines assumption the autofit function in GOLOGIT2 in Stata was used, which tests this assumption for each of the fitted explanatory variables and then identifies those variables where the assumption is violated, before fitting the models accordingly. After fitting these variables, several of the models failed to converge; so the dependent variable with five categories was collapsed into a new dependent variable with three categories: i.e. 'not happy at all' and 'not very happy' were combined to form 'not happy'; the 'fairly happy' remained as is; and the 'very happy' and 'extremely happy' were combined to form the 'happy' category.

The dependent variable of happiness is denoted as $Y_{i}$ in the equation below. The explanatory variables were added to the model sequentially until a suitable model was found. The fitted explanatory variables in the model are: age, gender, education, ethnicity, employment, ideas and personal growth. The fitted model is presented as:

\footnotetext{
$P\left(Y_{i}>j\right)=g(X \beta)$

$=\frac{\exp \left(\alpha_{j}+\beta_{0} * \text { gender }+\beta_{1} * \text { age }+\beta_{2} * \text { education }+\beta_{3} * \text { ethicity }+\beta_{4} * \text { employment }+\beta_{5} * \text { ideas }+\beta_{6} * \text { personal growth }\right)}{1+\left\{\exp \left(\alpha_{j}+\beta_{0} * g e n d e r+\beta_{1} * a g e+\beta_{2} * \text { education }\right.\right.}$

$=\frac{\left.\exp \left(\alpha_{j}+\beta_{0} * \text { gender }+\beta_{1} * \text { age }+\beta_{2} * \text { education }+\beta_{3} * \text { ethicity }+\beta_{4} * \text { emloyment }+\beta_{5} * \text { ideas }+\beta_{6} * \text { personal growth }\right)\right\}}{1+}$,

$=1,2, \ldots, M-1$
}

The results are summarised in Table 3 below: 
Table 3

Ordinal logistic regression results

\begin{tabular}{|c|c|c|c|c|c|c|}
\hline \multirow{2}{*}{ Variable } & \multicolumn{3}{|c|}{$\begin{array}{c}\text { Not happy vs (fairly happy and } \\
\text { happy) }\end{array}$} & \multicolumn{3}{|c|}{$\begin{array}{l}\text { (Not happy and fairly happy) } \\
\text { vs happy }\end{array}$} \\
\hline & Coefficient & $\begin{array}{l}\text { Odds } \\
\text { ratio }\end{array}$ & $\mathrm{p}$-value & Coefficient & $\begin{array}{l}\text { Odds } \\
\text { ratio }\end{array}$ & p-value \\
\hline \multicolumn{7}{|c|}{ Gender $($ Reference $=$ Female $)$} \\
\hline Male & 1.156 & 3.178 & $0.040^{*}$ & -0.316 & 0.729 & 0.224 \\
\hline \multicolumn{7}{|c|}{ Age (Reference = $18-30$ years) } \\
\hline $31-45$ years & -1.160 & 0.313 & $0.042^{*}$ & 0.052 & 1.053 & 0.881 \\
\hline $46-59$ years & -0.238 & 0.789 & 0.534 & -0.238 & 0.789 & 0.534 \\
\hline $60-75$ years & -2.261 & 0.104 & $0.021^{*}$ & -0.338 & 0.713 & 0.500 \\
\hline \multicolumn{7}{|c|}{ Education (Reference = Postgraduate) } \\
\hline Grade 4-11 & -1.771 & 0.170 & $0.022^{*}$ & 0.462 & 1.588 & 0.467 \\
\hline Matric & -0.071 & 0.931 & 0.874 & -0.071 & 0.931 & 0.874 \\
\hline Diploma & 0.085 & 1.089 & 0.857 & 0.085 & 1.089 & 0.857 \\
\hline Degree & 0.346 & 1.413 & 0.533 & 0.346 & 1.413 & 0.533 \\
\hline \multicolumn{7}{|c|}{ Ethnicity (Reference = White) } \\
\hline Black & -1.306 & 0.271 & $0.001^{*}$ & -1.306 & 0.271 & $0.001^{*}$ \\
\hline Coloured & -1.158 & 0.314 & $0.025^{*}$ & -1.158 & 0.314 & $0.025^{*}$ \\
\hline Indian & -0.356 & 0.700 & 0.337 & -0.356 & 0.700 & 0.337 \\
\hline \multicolumn{7}{|c|}{ Employment (Reference = Wage earners) } \\
\hline Self-employed & 1.492 & 4.444 & $0.048^{*}$ & 1.492 & 4.444 & $0.048^{*}$ \\
\hline \multicolumn{7}{|c|}{ I am able to contribute my personal ideas in the work environment (Reference $=$ No) } \\
\hline Yes & 2.294 & 9.919 & $0.000^{*}$ & 0.287 & 1.332 & 0.486 \\
\hline \multicolumn{7}{|c|}{ I am experiencing personal growth in the work environment (Reference=No) } \\
\hline Yes & 1.206 & 3.341 & $0.000^{*}$ & 1.206 & 3.341 & $0.000^{*}$ \\
\hline Constant & 1.389 & 4.009 & 0.053 & -0.340 & 0.712 & 0.596 \\
\hline
\end{tabular}

When comparing males to females, it was found that the males tended to be 3.18 times more likely than females to be 'fairly happy' or 'happy', rather than 'not happy' (Table 3). However, it must be noted that in the previous section, the independent sample t-test did not show any significant difference between males and females with respect to their average happiness. This is possibly due to the fact that the independent sample t-test operates differently from the ordinal logistic regression, as these are independent techniques. Ordinal logistic regression makes use of the probability or likelihood of events occurring whilst the independent sample t-test makes use of the sampling mean under the equal or unequal variances assumption.

The ordinal regression reveals that the 31-45- year age group tended to be 0.313 times less likely than the 18-30- year age group to be 'fairly happy' or 'happy' as compared to being 'not happy'. The results also indicate that the senior citizen group in the 60-75- year age category was 0.104 times less likely than the younger 18-30- age group to be 'fairly happy' and 'happy': when compared to being 'not happy'. Hence, within the current research setting, young individuals in the 18-30- year group tended to be happier than the older respondents.

The research also shows that the respondents with a Grade 4-11 education were about 0.17 times less likely than those with a postgraduate education to be 'fairly happy' or 'happy' when compared to being 'not happy'. Further, the research indicates that the black race group was about 0.271 times less likely than the white group to be 'fairly happy' or 'happy' when compared to being 'not happy'. This trend is also found in the coloured race group: respondents in the latter ethnic group were about 0.314 times less likely than the white race group to be 'fairly happy' or 'happy' when compared to being 'not happy'. The result that blacks were found to be less happy than whites tends to accord with the findings of Moller (2011) that although whites have lost political dominance with the end of apartheid, they continue to experience above average levels of 
happiness and life satisfaction, relative to blacks. Studying happiness between ethnic groups of both married and cohabitant individuals, Botha and Booysen (2013), also found that whites and coloureds were happier than blacks. Similarly, Blaauw and Pretorius (2013) found that the African ethnic group had the lowest reported levels of happiness relative to other groups in South Africa.

In the present study, it was also found that self-employed respondents were 4.44 times more likely than wage earners to be 'fairly happy' or 'happy', rather than 'not happy'. The result that entrepreneurs were happier than wage earners tends to accord with the findings of Hundley (2001) and Benz and Frey (2008), as indicated earlier. In the work environment it was also revealed that those respondents who were able to contribute their personal ideas were approximately 10 times (9.919) more likely than those who were not able to contribute their personal ideas, to be 'fairly happy' or 'happy' as opposed to 'not happy'.

Respondents who were experiencing personal growth in the work environment were found to be 3.341 times more likely than those respondents who were not perceived to be experiencing personal growth in the work situation, to be 'fairly happy' or 'happy', rather than 'not happy'. Thus, it appears that a society could be happier if there were more entrepreneurs in the economy to provide opportunities for labour to grow within the firm, and enable them to contribute their initiatives and ideas to the workplace. It is more likely that individuals who are happy would generate a positive influence as they are better 'citizens' in society and in the work-place (Putman, 2000). Taking initiative entails being pro-active in doing things and finding solutions to problems rather sitting back and waiting for orders from the 'boss' to be told what to do. This contributes to a sense of fulfillment among labour, inspiring them to achieve even more for higher levels of happiness (Ashcroft \& Caroe, 2007). Taking initiative also implies assuming some risk for labour or the entrepreneur, as things may not always work as expected. But the alternative is doing nothing and taking no responsibility. Choosing the latter option means no new learning can take place. As happiness is thus apparently linked to some form of risk-taking and exercise of creativity at work, entrepreneurs may be encouraged to create a supportive, engaging environment for labour to freely submit and share positive ideas with the aim of attaining higher levels of organisational development, personal growth and happiness.

When comparing happiness within ethnic groups, the black race group was about 0.271 times less likely than the white race group to be 'happy' as opposed to 'not happy' and 'fairly happy' (see last columns in Table 3). The coloured race group was about 0.314 times less likely to be 'happy' than the white group. The work environment exhibited a trend similar to the previous comparison. The research also revealed that self- employed respondents were 4.44 times more likely than wage- earners to be 'happy', as opposed to being 'not happy' and 'fairly happy'. This trend is evident when comparing being 'happy' as opposed to being 'not happy' and 'fairly happy', in that those respondents who were able to contribute their personal ideas were approximately 10 times (9.919) more likely than those who were not able to contribute their personal ideas to be 'happy'. Once again, respondents who were perceived to be experiencing personal growth in the work environment were 3.341 times more likely than those respondents who were not experiencing personal growth in the work situation to be 'happy', as opposed to being 'fairly happy' and 'not happy'. Several interaction terms were assessed by including them in the model but none of them were found to be significant and so they have not been reported in the results.

Based on the results of the current case study, the overall trends in the regression analysis revealed that the white race group was generally the happiest of the ethnic groups, thus suggesting that race or ethnicity seems to be a significant predictor of happiness in the current study. It was also found that gender is a predictor of being 'fairly happy' and 'happy', in that males were happier than females. Despite the stress associated with entrepreneurship, entrepreneurs were generally happier than wage-earners, possibly because they were more independent and their own bosses. To be given opportunities to contribute personal ideas and opportunities for personal growth in the work environment was also shown to be significant in influencing happiness levels. 


\section{Limitations of the study}

This study is not without limitations. The small sample size, partly resulting from resource constraints, is one limitation. A larger sample size, consisting of a greater number of entrepreneurs and workers, with an identification of different functional roles in different activities, might have strengthened the results. Secondly, this study was based in the Pietermaritzburg region and a broader study that extended to other provinces might have provided better estimates of happiness for a wider regional context. Many variables, including health conditions, emotional intelligence, religiosity, depression and work stress affect happiness (Seligman, 2004; Huffington, 2014). These variables could also be considered in a broader study. Thus, owing to the above limitations, the results or inferences drawn from the study should be treated with some caution.

\section{$6 \quad$ Discussions of results and tentative policy implications}

The pursuit of happiness is a primary objective of human beings. All the things individuals want are typically perceived to be the means to the end of happiness. But many individuals are unhappy, and there is no single determinant that exclusively explains an overall, subjective sense of wellbeing.

Education, gender and being married with children were found, in this case study, to be significantly associated with well-being. While the birth of a child is generally greeted with great joy in a family, having many children was found to contribute to a decrement in individual happiness. Educated people tend to be happier than their less educated counterparts (Botha \& Booysen, 2013). Education is also linked to higher productivity and income, as well as occupational status. Individuals with greater talents and wider community networks have wider choices in life and are perceived to be happier relative to those with lower skills or networks (Sen, 2010; Blaauw \& Pretorius, 2013). However, more education could lead to greater expectations, and if higher aspiration levels cannot be realised, people could be less happy, seen in this study, where individuals with post-graduate degrees were found to be relatively less happy than those with a degree or diploma.

In a post-apartheid South Africa the racial barriers are being dismantled with governmental policy interventions and this is a positive step for the well-being of the entire country. Although whites are perceived to be happier than other groups (Blaauw \& Pretorius, 2013; Ebrahim, Botha \& Snowball, 2013), with the implementation of empowerment and affirmative legislation, this gap is likely to be narrowed as more formerly disadvantaged people with capabilities are brought into the mainstream enterprise economy. As they become more empowered and engage in more successful entrepreneurial activities, their happiness levels are likely to increase. Entrepreneurs were found to be happier than wage earners. Although being one's own boss as a self-employed person is important for subjective happiness (Benz \& Frey, 2008), employees could still be happy. This is more likely to happen if they were forward thinking and could take initiatives in a work environment that provided them with the space to grow and develop.

In work situations where there is trust and reciprocity between the different role players, there is improved social capital, fostering higher levels of happiness. This suggests that happy people are contented not with idleness, but with relational activeness in making things happen and using their talents and resources to deliver in different capacities (Putman, 2001). The productive flow experiences in turn may boost their sense of self-esteem, social bonding and well-being. On a normative level, persistent inequalities in life satisfaction or work treatment between genders are not desirable since inequality increases social distance between groups of individuals. With greater equality in treatment at work, people are more caring of one another and there is greater trust that impacts positively on the well-being of individuals (Wilkinson \& Pickett, 2010).

Although the chi-square test indicated that income is strongly related to happiness, the probability of a higher income earner being far happier than a low income earner was not found to be significant in the ordinal logistic model. The income variable was not included since its presence affected the convergence of the ordinal logistic regression model. The ordinal regression 
model had some variables that were non-significant, whilst the selfsame factors were significant under the chi-square test. This arose as both statistical approaches are independent of each other in the estimation technique, or due to the presence of confounding or suppressor variables. This might be true in the case of income, as it was found not to be significant in the logistic regression, but was significant in the chi-square testing and the ANOVA. People with low incomes and education levels can still be happy and find life satisfying. The work environment in which one earns an income is perhaps more important in contributing to one's happiness than income per se. Individuals who have a positive work environment are prepared to take on additional commitments for the advancement of the firm (Frey \& Stutzer, 2002; Diener \& Diener, 2008).

People derive a degree of satisfaction from how they feel at work, as entrepreneurs and workers. Work function (chi-square=29.535; $\mathrm{p}=0.000$ ) and employment status (chi-square= 12.273; $\mathrm{p}=0.015$ ) were significantly associated with happiness. Working in an unfulfilling environment can be very stressful for entrepreneurs and frustrating for employees. Stress at work can be displaced into the family environment, impacting adversely on household happiness. Employers should be encouraged to create more fulfilling or warm work environments for their employees and allow them the space to contribute ideas for personal development and enterprise growth.

\section{Conclusion}

The search for a satisfying life of endeavour is an important individual and economic goal. Although the pursuit of happiness is never easy or complete, every individual has the potential to be a happier person and to make others happier too. Enhanced life satisfaction is partly related to personal relationships and engagement in work. On average, happier people tend be married, educated and have between one and three children, and tend to be treated fairly at work. As work takes up a significant part of our lives, it is vital that individuals, as risk-taking entrepreneurs or as salaried earners, are happy at work and support a culture of happiness across all ethnic groups. People are the heart of a firm. Treating individuals well and strengthening teambuilding and wellness relationships that deliver greater happiness to everyone constitute a desirable social goal. It does not make sense to have a workforce that is miserable. Although employees may have a lower level of happiness than entrepreneurs, those who are self-employed and employers must ensure that all signs or causes of unhappiness are effectively removed so that a more engaged workforce comes about. Happy people are generally more productive individuals who contribute significantly to making firms successful. A better understanding of the drivers of subjective wellbeing is thus critical for enhancing happiness at the individual and corporate levels.

\section{Acknowledgements}

The authors wish to acknowledge and express their sincere thanks to two anonymous reviewers for their valuable and helpful comments on an earlier version of this paper. Our thanks also go to C. Bassage, Prof. John Luiz and Prof. Pieter Buys.

\section{References}

AGRESTI, A. 2006. Categorical data analysis (2 ${ }^{\text {nd }}$ ed.) New York: Wiley and Sons.

ALLISON, P.D. 2005. Logistic regression using SAS: Theory and application. Cary : NC:SAS Institute Inc. ASHCROFT, J. \& CAROE, P. 2007. Thriving lives: Which way for well-being? Cambridge: Relationships Foundation.

BENZ, M. \& FREY, B. 2008. Being independent is a great thing: Subjective evaluations of self-employment and hierarchy, Economica, 75(298):362-383.

BLANCHFLOWER. D. \& OSWALD, A. 1992. Entrepreneurship, happiness and supernormal returns: Evidence from Britain and the US. Available at: http://ideas.repec.nbr.org/papers/W4228.pdf [accessed 201410-10]. 
BLAAUW, P., BOTHA, I., SCHENCK, R. \& SCHOEMAN, C. 2013. Happy in the informal economy? A case study of well-being among day labourers in South Africa. International Business \& Economics Research Journal, 12(6):635-654.

BLAAUW, D. \& PRETORIUS, A. 2013. The determinants of subjective well-being in South Africa - an exploratory enquiry. Journal of Economic and Financial Services, 6(1):179-194.

BOTHA, F. \& BOOYSEN, F. 2013. Family functioning and life satisfaction and happiness in South African households. ERSA Working Paper no. 363.

BOTHA, F. \& BOOYSEN, F. 2013. The gold of one's ring is not far more precious than the gold of one's heart: Reported life satisfaction among married and cohabiting South African adults. Journal of Happiness Studies, 14:433-456.

BRUNI, L. \& PORTA, P.L. 2007. Handbook on the economics of happiness, Cheltenham: Edward Elgar. CLARK, A.E. \& OSWALD, A.J. 1994. Unhappiness and employment. Economic Journal, 104:648-659. COAKES, S. \& STEED, L.K. 2003. SPSS without anguish. Queensland: John Wiley and Sons.

COYLE, D. 2012. The economics of enough. Princeton: Princeton University Press.

DEVORE, J.L. \& BERK, K.N. 2012. Modern mathematical statistics with application. New York: Springer. DIENER, E. \& BISWAS-DIENER, R. 2008. Happiness: Unlocking the mysteries of psychological wealth. London: Blackwell.

DUTT, A.K. \& RADCLIFF, B. 2009. Happiness, economics and politics. Cheltenham: Edward Elgar.

EASTERLIN, R. 1995. Will raising the incomes of all Increase the happiness of all? Journal of Economic Behaviour and Organisation, 27(1):35-47.

EASTERLIN, R. 2001. Income and happiness: Toward a unified theory. Economic Journal, 111:465-484. EBRAHIM, A., BOTHA, F. \& SNOWBALL, J.D. 2013. Determinants of life satisfaction among race groups in South Africa. Development Southern Africa, 30(2):168-185.

ECONOMIST. 2010, December 18. The U-bend of life: Age and happiness. The Economist, 33-36.

FRANK, R.H. 1999. Luxury fever. New York: Free Press.

FREY, B.S. 2008. Happiness: A revolution in economics. Cambridge: MIT Press.

FREY, B.S. \& STUTZER, A. 2002. What can economists learn from happiness research? Journal of Economic Literature, 40(3):402-435.

FREY, B.S. \& STUTZER, A. 2000. Happiness, economy and institutions. Economic Journal, 110:918-938.

GREYLING, T. 2011. Measuring and understanding the well-being of Gauteng city-region's population. Paper presented at the Biannual Conference of the Economic Society of South Africa, University of Stellenbosch, South Africa, 4-7 September 2011.

HEADEY, B., MUFFELS, R. \& WAGNER, G.G. 2010. Long-running German panel survey shows that personal and economic choices, not just genes, matter for happiness. PNAS, 107(42):17922-17926.

HELLIWELL, J., BARRINGTON-LEIGH, C., HARRIS, A. \& HUANG, H. 2010. International evidence on the social context of well-being. In E. Diener, J. Helliwell, \& D. Kahneman (eds.) International differences in well-being. New York: Harvard University Press.

HELLIWELL, J., LAYARD, R. \& SACHS, J. (eds.) 2013. World happiness report. The Earth Institute, Columbia University.

HINKS, T. \& GRUEN, C. 2007. What is the structure of South African happiness equations? Evidence from quality of life surveys. Social Indicators Research, 82:311-336.

HDR, 2011. Human development report 2011: Sustainability and equity - A better future for all. UNDP. New York: Palgrave Macmillan.

HUFFINGTON, A. 2014. Thrive. United Kingdom: W. H. Allen.

HUNDLEY, G. 2001. Why and when are self-employed more satisfied with their work? Industrial Relations, 40(2):293-316.

INGLEHART, R., FOA, R., PETERSON, C. \& WEIZEL, C. 2008. Development, freedom, and rising happiness: A global perspective (1981-2007). Perspectives on Psychological Science, 3(4):264-85. JAMES, O. 2007. Affluenza. London: Vermilion.

KAHNEMAN, D. 2012. Thinking, fast and slow. London: Penguin. 
KENNY, C. 2005. Does development make you happy? Subjective well-being and economic growth in developing countries. Social Indicators Research, 73:199-219.

KINGDON, G. \& KNIGHT, J. 2006. Subjective well-being: Poverty vs income poverty and capabilities poverty. The Journal of Development Studies, 42(7):1199-1224.

LANE, E. 2001. The loss of happiness in market democracies. New Haven: Yale University Press.

LAYARD, R. 2006. Happiness and public policy: A challenge to the profession. Economic Journal, 116: C24-C33.

LAYARD, R. 2011. Happiness: Lessons from a new science. London: Penguin.

MAHADEA, D. \& RAWAT, T. 2008. Income, growth and happiness: An exploratory study. South African Journal of Economics, 76 (2):276-290.

MOLLER, V. 2011. Happiness trends under democracy: Where will the New South African set-level come to rest? Journal of Happiness Studies, 2(1):33-53.

MOLLER, V. 2007. Satisfied and dissatisfied South Africans: Results from the general household survey in international comparison. Social Indicators Research, 81:389-415.

NG, Y.K. 1997. A case for happiness, cardinalism, and interpersonal comparability. Economic Journal, (445):1848-58.

OSWALD, A. 1997. Happiness and economic performance, Economic Journal, 107(445):1815-1831.

PORTER, E. 2011. The price of everything. London: Heinemann.

POSEL, D.R. \& CASALE, D.M. 2011. Relative standing and subjective well-being in South Africa: The role of perceptions, expectations and income mobility. Social Indicators Research, 104(2):195-223.

POWDTHAVEE, N. 2007. Happiness and the standard of living: The case of South Africa. In L. Bruni and P.L. Porta (eds.) Handbook on economics of happiness. (447-486), MA, USA: Edward Elgar.

POWDTHAVEE, N. 2011. The happiness equation. London: Icon Books.

PUTMAN, R.D. 2000. Bowling alone. London: Simon \& Schuster.

PUTMAN, R.D. 2001. Social capital: Measurement and consequences. Canadian Journal of Policy Research, 2(1):41-51.

SACHS, J. 2012. The price of civilization. London: Vintage.

SELIGMAN, E.P. 2004. Authentic happiness. New York: Free Press.

SEN, A.K. 2010. The idea of justice. London: Penguin.

STEVENSON, B. \& WOLFERS, J. 2008. Economic growth and subjective well-being: Reassessing the Easterlin paradox. Brookings Papers on Economic Activity, 1:1-102.

STUTZER, A. 2001. What are the sources of happiness? In B.S. Frey (ed.) Inspiring economics: Human motivation in the political economy. (135-146). Northampton: Edward Elgar.

VEENHOVEN, R. 1993. Happiness in nations: Subjective appreciation of life in 56 nations. Rotterdam: Erasmus University.

VEENHOVEN, R. 1997. The utility of happiness. Social Indicators Research, 20:333-54.

VEENHOVEN, R. 2012. Happiness in South Africa. World database of happiness. Rotterdam: Erasmus University. Available at: http://worlddatabaseofhappiness.eur.nl [accessed 2014-05-05].

VEENHOVEN, R. \& HAGERTY, M. 2006. Happiness in nations 1946-2004: A reply to Easterlin. Social Indicators Research, 79:421-436.

WILKINSON, R. \& PICKETT, K. 2010. The spirit level: Why equality is better for everyone. London: Penguin.

WILLIAMSON, R. 2006. Generalized ordered logit/partial proportional odds models for ordinal dependent variables. The Stata Journal, 6(1):58-82. 